\title{
Effect of Crop Establishment Methods and Nitrogen Management on Growth, Yield Attribute and Yield of Rice (Oryza sativa L.) under Lowland Condition of Manipur Valley
}

\author{
Khwairakpam Lenin Singh*, Edwin Luikham, K. Nandini Devi and Priyanka Irungbam \\ Department of Agronomy, College of Agriculture, Central Agricultural University, \\ Imphal, Manipur-795004, India \\ *Corresponding author
}

\section{A B S T R A C T}

\begin{tabular}{|c|}
\hline Keywords \\
\hline $\begin{array}{l}\text { Rice, Crop } \\
\text { establishment } \\
\text { methods, Nitrogen } \\
\text { management, } \\
\text { Effective tiller, } \\
\text { Yield }\end{array}$ \\
\hline Article Info \\
\hline $\begin{array}{l}\text { Accepted: } \\
\text { 04 October } 2019 \\
\text { Available Online: } \\
10 \text { November } 2019\end{array}$ \\
\hline
\end{tabular}

Keywords

Rice, Crop methods, Nitrogen management, Effective tiller, Yield 10 November 2019

\begin{abstract}
A field experiment was conducted during pre-kharif season of 2016 and 2017 at Research Farm, College of Agriculture, Central Agricultural University, Imphal, Manipur, to study the effect of crop establishment methods and nitrogen management on growth and yield of rice (Oryza sativa L.). Rice cultivar CAU-R3 was grown with twelve treatment and laid out in split plot design, keeping crop establishment methods viz. C1-system of rice intensification (SRI), C2-integrated crop management (ICM) and C3-conventional as main plot with four nitrogen management viz. N1-100\% recommended dose of nitrogen (RDN) through urea, N2-100\% RDN through farm yard manure (FYM), N3-75\% RDN through urea + $25 \%$ RDN through FYM and N4-50\% RDN through urea $+50 \%$ RDN through FYM in sub-plot, replicated thrice. Studies from pooled data found out that C1 contributed the highest value of growth parameter and yield attribute as compared to $\mathrm{C} 2$ and $\mathrm{C} 3$. Among the nitrogen management N3 produces the highest growth parameter at all the stages of crop except at 30 days after transplanting than other three nitrogen management as well as highest value of yield attribute and yield. However, rice grown under ICM produces significantly higher yield than conventional method but at par with SRI.
\end{abstract}

\section{Introduction}

Rice is among the three most important crop and staple food crop for more than one-third of world's population (Prasad et al., 2010). South-East Asia alone will require 275 million tonnes of rice to meet the growing population by 2030 (Subbiah et al., 2001). It is the staple food of India which feed more than 60 percent of the total population of country. India has the largest area under rice cultivation (44.3 million ha), amounting for $29.40 \%$ of the global rice area. Many states of India have gradually converted from agriculture sector to industrial sector but states like Manipur due to topographic constrain it has to heavily depend 
on agriculture for their livelihood. In the state of Manipur also rice is the staple food and dominant crop which account for about 98 percent of the total food grain production of the state. More than half $(52.19 \%)$ of its population depend upon the agriculture sector (Economic survey of Manipur, 2016-17), especially the rice cultivation and the sector has a vital place in the economy of the state.

Manipur has a total geographical area of $22,327 \mathrm{~km}^{2}$ of which only about $231.19 \mathrm{~km}^{-2}$ land is available for agriculture. From the total gross crop area about 72 percent of the land is used for the cultivation of paddy. Farmer of Manipur mostly practices mono cropping with low cropping intensity of $143.26 \%$. In order to meet the increased demand of food grain due to high growth of population with these limited land resource farmer from the state need to practice double cropping with proper agronomic practices. Good agronomic practices include application of right dose of fertilizer specially nitrogen, proper irrigation, weed management, optimum plant densities and sustainability of the farmers. Besides, growing of rice during kharif season it can be grown successfully during pre-kharif season by proper irrigation without compromising the yield. Growing rice during pre-kharif season not only increases the cropping intensity of the region but it also increases economic status of the farmer.

Among the agronomic practices maintaining optimum plant density in rice cultivation is the pre-requisite for better utilization of above ground and ground resources and thus ensures proper growth in their aerial and underground part. A densely growing crop may have many limitations in utilizing these resources. Alternate method of rice cultivation like system of rice intensification (SRI) and integrated crop management (ICM) have the potential to meet the increased rice demand and utilized the resources in a more sustainable manner than the conventional method of rice cultivation. It has many advantages such as higher water use efficiency, more efficient use of applied chemical fertilizer and manure, high tolerance to water scarcity and reduced cost of cultivation due to lower labour input.

Nitrogen $(\mathrm{N})$ is the most limiting nutrient for rice growth and yield in almost all environments (Yoshida, 1981 and Roy and Mishra, 1999). Hence application of fertilizer nitrogen is an essential input for increasing the crop productivity in rice. It is estimated that $24 \%$ increase in Asian rice was attributed to use of fertilizers, mainly nitrogen. Generally rice crops need a higher amount of $\mathrm{N}$ to achieve a good yield. However, it is subjected to huge losses, as its efficiency in rice is less than $40 \%$ of the applied N. These losses could be minimized greatly by substituting chemicals fertilizer with organic manure in an integrated manner. There is continuous supply of $\mathrm{N}$ by organic manures and tying up of inorganic soil $\mathrm{N}$ prevents its loss through denitrification, volatilization or leaching (Gill and Meelu, 1982 and Singh, 1984). Integrated approaches of organic and inorganic nutrients management have shown an increased efficiency of applied $\mathrm{N}$ fertilizer in rice (Buresh and De Datta, 1991). This is because of minimal loss of $\mathrm{N}$ in case of organic sources and $\mathrm{N}$ was available to the crop for longer period. Furthermore, the dynamic nature of $\mathrm{N}$ and its propensity for loss from soil-plant systems creates a unique and challenging environment for its efficient management (Fageria and Baligar, 2005).

Keeping in mind the need of optimum plant spacing and good nitrogen management practices the present research was undergone during pre-kharif season 2016 and 2017 with the aim to find out different effect on rice due to crop establishment methods and nitrogen management. 


\section{Materials and Methods}

A field experiment entitled "Effect of crop establishment methods and nitrogen management on growth, yield attribute and yield on rice (Oryza sativa L.) under lowland condition on Manipur valley" was conducted in 2016 and 2017 during the pre-kharif season at the Research Farm, College of Agriculture, Central Agricultural University, Imphal. The experimental field was situated at 24051 'N latitude and 93056"E longitude at an altitude of 790m above mean sea level. The soil of the experimental site was clay in texture with acidic in $\mathrm{pH}$ (5.4). Medium in available nitrogen $\left(346.06 \mathrm{~kg} \mathrm{ha}^{-1}\right)$, phosphorus $(30.78$ $\left.\mathrm{kg} \mathrm{ha}^{-1}\right)$ and potassium $\left(248.12 \mathrm{~kg} \mathrm{ha}^{-1}\right)$ and high in organic carbon $(2.36 \%)$. The total annual rainfall for the year 2016 was 1850.9 $\mathrm{mm}$ and in 2017 it was $2439.4 \mathrm{~mm}$.

The experimental field was properly level after ploughing by using leveler and plot are made according to the required size $\left(4 \times 3 \mathrm{~m}^{2}\right)$ for conducting research. Land was divided into individual experimental plots with the proper arrangement of bunds and irrigation channel as per the lay out specifications. Nine block each contain four sub-plot was made for fitting the treatment. The experiment was laid out in split plot design keeping crop establishment in the main plot and nitrogen management in the sub-plot. The factor of experiment include three crop establishment methods viz. C1- SRI $\left(25 \times 25 \mathrm{~cm}^{2}\right), \mathrm{C} 2-\mathrm{ICM}$ $\left(20 \times 20 \mathrm{~cm}^{2}\right), \mathrm{C} 3$-conventional methods $(20 \mathrm{x}$ $10 \mathrm{~cm}^{2}$ ) and four nitrogen management practices viz. N1-100\% $\mathrm{N}$ recommended dose of nitrogen (RDN) through urea, N2-100\% N through farm yard manure (FYM), N3-75\% N RDN through urea $+25 \% \mathrm{~N}$ through FYM and $\mathrm{N} 4-50 \% \mathrm{~N}$ RDN through urea $+50 \% \mathrm{~N}$ through FYM with three replication. Same treatment was superimposed on the same plot for the second year also to study the cumulative effect of the treatment. A short duration rice cultivar CAU-R3 was used as test crop for the experiment. Healthy and disease free seed were selected for raising the seedling. The required seed was soaked in water and removed after 48 hour and tight in gunny bag after mixing with Carbendazim @ $2.5 \mathrm{~g} \mathrm{~kg}^{-1}$ seed till it sprouted. The sprouted seed were taken in tray and sown in the nursery bed. Seed was sown on $19^{\text {th }}$ February in both the year and transplant according to the required age of the crop establishment methods. In SRI one seedling were transplanted at the age of ten days, two seedlings at 15 days for ICM and three to four seedling at the age of twenty one days for conventional method. Gap filling was done after seven days to maintain the required plant population.

FYM was applied on the plot before ten days of transplanting according to the treatment. Half dose of nitrogen and full dose of phosphorus and potassium were applied as basal. The remaining half dose of nitrogen was applied at maximum tillering and panicle initiation stage. Alternate drying and wetting was maintained in SRI and ICM and sufficient standing water was kept on conventional method. Five plant samples were selected randomly from the net plot area which can represent the whole population and tagged for recording the reading of growth parameter and yield attribute. Growth parameter like plant height, tiller hill ${ }^{-1}$, leaf area index and dry matter production was recorded at 30 days interval. Plant height was measured from five representative samples and calculated the average in $\mathrm{cm}$. For taking dry matter production five plant samples were uprooted from the border areas and washed it in running water. The samples are further shade dried again to take out the moisture and keep in the oven at $70{ }^{\circ} \mathrm{C}$ till it attains constant weight. The weights are recorded in $\mathrm{g}$ hill ${ }^{-1}$. Leaf area index was estimated by using the formula by Watson (1952). 
LAI $=\left(\right.$ Leaf area per plant $\left.\left(\mathrm{cm}^{2}\right)\right) /($ Ground area $\left.\left(\mathrm{cm}^{2}\right)\right)$

Data for yield attribute like effective tiller hill $^{-1}$, panicle length, test weight, filled grain and unfilled grain was estimated from average of five sample plant from the net plot. Two border rows were removed to harvest the net plot area and keep it separately for each plot. To separate the grain and straw threshing was done followed by winnowing.

The data generated from both the year was analyzed using analysis of variance (ANOVA) and the difference between treatment means was tested for their statistical significance with appropriate critical difference (CD) at 5 per cent level of probability (Gomez and Gomez, 1984). The treatment where there is no significant difference it is denoted by "NS".

\section{Results and Discussion}

Effect of crop establishment methods and nitrogen management on growth parameter

SRI methods produce the tallest plant height as compare to ICM and CM at all the stages of rice (Table 1). While $\mathrm{CM}$ produces the shortest plant height due to more intra and inter competition among the rice plant for resource.

There is less competition for above ground and underground resources in SRI and ICM due to wider spacing and less plant population which lead to increase in resource use efficiency and further produce a healthier and stronger plant. Difference in plant height among the crop establishment methods were also reported by Munda et al., (2007) and Wahlang et al., (2015). Among the nitrogen management N3-75\% RDN + 25\% N through Urea, produces the tallest plant at all intervals except 30 DAT. Due to fast dissolving action of Urea and absorption by the plant it produces tallest plant height where 100\% nitrogen was applied through Urea, (N1) at 30 DAT (Table 1). FYM is a complete source of all plant nutrients which release slowly into the labile pool after decomposition and make it available for entire life of the rice.

After 30 DAT treatments N3-75\% RDN + $25 \% \mathrm{~N}$ through Urea, has started increasing height due to supply of nutrient from FYM. Production of dry matter ( $\mathrm{g} \mathrm{hill}^{-1}$ ) was also influence by both crop establishment and nitrogen management and also followed the same trend of plant height as the height is the result of more dry matter production in the plant (Table 3).

The number of tiller hill $^{-1}$ increases with increase in plant spacing and highest number of tiller was obtained from the SRI in all the stages of the crop (Table 2). The reason for more number of tillers in SRI might be due to transplanting of younger seedling and availability of more nutrients due to less number of plants. Tiller hill ${ }^{-1}$ increases from 30 to 90 days and highest rate of increase was observed at 60 DAT (Table 2).

Leaf area index (LAI) was also influence by crop establishment methods and highest LAI was observe in conventional method which might be due to more leaves because of more plant population per unit area, similar result was observed by (Archana Rajput et al., 2017). At 30 DAT the treatment N1-100\% $\mathrm{RDF}$ produces the highest number of tiller hill $^{-1}$ but at 60 and 90 DAT treatment N3 produces the highest number of tiller hill ${ }^{-1}$ the reason might be due to integration of FYM with chemical fertilizer in a right proportion which might be suitable for the soil in Manipur than N4-50\% RDN through urea + $50 \%$ RDN through FYM and N2-100\% from FYM alone (Rajnesh Tomar et al., 2018). N3 produces the highest LAI followed by N1, N4 and $\mathrm{N} 2$ at all the stages of the crop due to nitrogen management (Table 4). 
Effect of crop establishment methods and nitrogen management on yield attributes of rice

Yield attribute like effective tiller hill ${ }^{-1}$, panicle length and test weight play a significant role in giving higher yield. It was recorded from the five tagged plant sample collected on harvesting time. SRI produces significantly higher number of tiller hill $^{-1}$ (22.56) over conventional method (11.47) but at par with ICM (20.36) which was $9.75 \%$ more over ICM and $49.15 \%$ over conventional method (Table 5). Due to more spacing with less plant population SRI receive more sunlight energy and ground resources than ICM and conventional method (Islam et al., 2013).

Table.1 Effect of crop establishment methods and nitrogen management on plant height $(\mathrm{cm})$ at 30, 60 and 90 DAT

\begin{tabular}{|c|c|c|c|c|c|c|c|c|c|}
\hline \multirow[t]{2}{*}{ Treatment } & \multicolumn{3}{|c|}{30 DAT } & \multicolumn{3}{|c|}{ 60 DAT } & \multicolumn{3}{|c|}{90 DAT } \\
\hline & 2016 & 2017 & Pooled & 2016 & 2017 & Pooled & 2016 & 2017 & Pooled \\
\hline \multicolumn{10}{|l|}{$\begin{array}{c}\text { Crop } \\
\text { Establishment }\end{array}$} \\
\hline C1 & 49.01 & 51.49 & 50.25 & 71.92 & 81.32 & 76.62 & 91.70 & 94.66 & 93.18 \\
\hline C2 & 47.24 & 49.41 & 48.33 & 65.58 & 71.08 & 68.33 & 90.53 & 93.45 & 91.99 \\
\hline C3 & 41.13 & 43.40 & 42.27 & 63.06 & 68.28 & 65.67 & 88.30 & 90.68 & 89.49 \\
\hline SE(d) \pm & 2.55 & 2.56 & 1.38 & 2.76 & 4.18 & 2.87 & 5.25 & 4.79 & 2.01 \\
\hline $\mathrm{CD}(\mathrm{p}=0.05)$ & 7.09 & 7.12 & 3.38 & 7.67 & 11.60 & 7.96 & NS & NS & NS \\
\hline \multicolumn{10}{|l|}{$\begin{array}{c}\text { Nitrogen } \\
\text { Management }\end{array}$} \\
\hline N1 & 51.02 & 54.09 & 52.56 & 67.58 & 72.76 & 70.17 & 92.40 & 94.66 & 93.53 \\
\hline N2 & 41.42 & 43.55 & 42.49 & 61.58 & 67.83 & 64.70 & 84.56 & 87.09 & 85.83 \\
\hline N3 & 46.12 & 48.71 & 47.42 & 73.55 & 83.67 & 78.61 & 95.23 & 99.15 & 97.19 \\
\hline N4 & 44.62 & 46.04 & 45.33 & 64.70 & 70.00 & 67.35 & 88.52 & 90.83 & 89.68 \\
\hline $\mathrm{SE}(\mathrm{d}) \pm$ & 2.24 & 2.13 & 1.37 & 2.68 & 2.79 & 1.75 & 3.18 & 2.69 & 1.94 \\
\hline $\mathrm{CD}(\mathrm{p}=0.05)$ & 4.71 & 4.47 & 2.87 & 5.63 & 5.86 & 3.68 & 6.69 & 5.65 & 4.08 \\
\hline \multicolumn{10}{|l|}{ Interaction } \\
\hline $\begin{array}{l}\text { SE }(d) \pm \text { for NM } \\
\text { on CE methods }\end{array}$ & 3.88 & 3.68 & 2.37 & 4.64 & 4.83 & 3.03 & 5.52 & 4.65 & 3.36 \\
\hline $\begin{array}{l}\mathrm{CD}(\mathrm{p}=0.05) \text { for } \\
\text { NM on } \mathrm{CE} \\
\text { methods }\end{array}$ & NS & NS & NS & NS & NS & NS & NS & NS & NS \\
\hline $\begin{array}{l}\mathrm{SE}(\mathrm{d}) \pm \text { for } \mathrm{CE} \\
\text { methods on } \mathrm{NM}\end{array}$ & 4.02 & 3.89 & 2.37 & 4.68 & 5.53 & 3.62 & 6.59 & 5.78 & 3.39 \\
\hline $\begin{array}{c}\text { CD }(p=0.05) \text { for } \\
\text { CE methods on } \\
\text { NM }\end{array}$ & NS & NS & NS & NS & NS & NS & NS & NS & NS \\
\hline
\end{tabular}


Table.2 Effect of crop establishment methods and nitrogen management on tiller hill ${ }^{-1}$ at 30, 60 and 90 DAT

\begin{tabular}{|c|c|c|c|c|c|c|c|c|c|}
\hline \multirow[t]{2}{*}{ Treatment } & \multicolumn{3}{|c|}{ 30 DAT } & \multicolumn{3}{|c|}{ 60 DAT } & \multicolumn{3}{|c|}{90 DAT } \\
\hline & 2016 & 2017 & Pooled & 2016 & 2017 & Pooled & 2016 & 2017 & Pooled \\
\hline \multicolumn{10}{|l|}{$\begin{array}{c}\text { Crop } \\
\text { establishment }\end{array}$} \\
\hline $\mathrm{C} 1$ & 7.82 & 8.27 & 8.05 & 15.82 & 16.42 & 16.12 & 23.12 & 23.97 & 23.54 \\
\hline $\mathrm{C} 2$ & 6.28 & 6.81 & 6.55 & 13.95 & 14.88 & 14.41 & 21.20 & 22.41 & 21.80 \\
\hline $\mathrm{C3}$ & 3.77 & 4.00 & 3.89 & 6.75 & 7.05 & 6.90 & 9.72 & 10.97 & 10.35 \\
\hline $\mathrm{SE}(\mathrm{d}) \pm$ & 0.48 & 0.65 & 0.53 & 0.71 & 0.57 & 0.47 & 0.84 & 1.02 & 0.61 \\
\hline $\mathrm{CD}(\mathrm{p}=0.05)$ & 1.34 & 1.80 & 1.48 & 1.98 & 1.58 & 1.31 & 2.34 & 2.83 & 1.69 \\
\hline \multicolumn{10}{|l|}{$\begin{array}{c}\text { Nitrogen } \\
\text { management }\end{array}$} \\
\hline N1 & 6.48 & 7.17 & 6.83 & 13.33 & 13.61 & 13.47 & 18.33 & 19.50 & 18.92 \\
\hline N2 & 5.33 & 5.68 & 5.50 & 9.47 & 10.12 & 9.80 & 16.61 & 17.51 & 17.06 \\
\hline N3 & 6.20 & 6.50 & 6.35 & 14.26 & 14.83 & 14.55 & 19.56 & 20.94 & 20.25 \\
\hline N4 & 5.82 & 6.09 & 5.96 & 11.62 & 12.56 & 12.09 & 17.55 & 18.50 & 18.03 \\
\hline $\mathrm{SE}(d) \pm$ & 0.26 & 0.64 & 0.32 & 0.45 & 0.53 & 0.38 & 0.76 & 0.64 & 0.59 \\
\hline $\mathrm{CD}(\mathrm{p}=0.05)$ & 0.54 & NS & 0.67 & 0.94 & 1.11 & 0.79 & 1.59 & 1.35 & 1.25 \\
\hline \multicolumn{10}{|l|}{ Interaction } \\
\hline $\begin{array}{l}\mathrm{SE}(\mathrm{d}) \pm \text { for NM on } \\
\text { CE methods }\end{array}$ & 0.44 & 1.10 & 0.55 & 0.77 & 0.92 & 0.65 & 1.31 & 1.11 & 1.03 \\
\hline $\begin{array}{c}\mathrm{CD}(\mathrm{p}=0.05) \text { for } \\
\text { NM on } \mathrm{CE} \\
\text { methods }\end{array}$ & NS & NS & NS & NS & NS & NS & NS & NS & NS \\
\hline $\begin{array}{l}\text { SE }(d) \pm \text { for CE } \\
\text { methods on NM }\end{array}$ & 0.57 & 1.11 & 0.66 & 0.91 & 0.94 & 0.70 & 1.35 & 1.31 & 1.03 \\
\hline $\begin{array}{l}\mathrm{CD}(\mathrm{p}=0.05) \text { for } \mathrm{CE} \\
\text { methods on } \mathrm{NM}\end{array}$ & NS & NS & NS & NS & NS & NS & NS & NS & NS \\
\hline
\end{tabular}


Table.3 Effect of crop establishment methods and nitrogen management on dry matter production $\left(\mathrm{g} \mathrm{hill}^{-1}\right.$ ) during 30, 60 and 90 DAT

\begin{tabular}{|c|c|c|c|c|c|c|c|c|c|}
\hline \multirow[t]{2}{*}{ Treatment } & \multicolumn{3}{|c|}{30 DAT } & \multicolumn{3}{|c|}{ 60 DAT } & \multicolumn{3}{|c|}{90 DAT } \\
\hline & 2016 & 2017 & Pooled & 2016 & 2017 & Pooled & 2016 & 2017 & Pooled \\
\hline \multicolumn{10}{|l|}{$\begin{array}{c}\text { Crop } \\
\text { establishment }\end{array}$} \\
\hline C1 & 3.88 & 4.00 & 3.94 & 20.98 & 21.17 & 21.07 & 33.12 & 33.32 & 33.22 \\
\hline C2 & 2.69 & 2.76 & 2.73 & 13.54 & 13.68 & 13.61 & 21.94 & 22.08 & 22.01 \\
\hline $\mathrm{C} 3$ & 0.96 & 1.23 & 1.09 & 6.43 & 6.46 & 6.44 & 9.61 & 9.74 & 9.68 \\
\hline $\mathrm{SE}(\mathrm{d}) \pm$ & 0.15 & 0.17 & 0.13 & 0.83 & 0.86 & 0.66 & 0.91 & 0.80 & 0.82 \\
\hline $\mathrm{CD}(\mathrm{p}=0.05)$ & 0.40 & 0.48 & 0.37 & 2.31 & 2.38 & 1.84 & 2.54 & 2.23 & 2.28 \\
\hline \multicolumn{10}{|l|}{$\begin{array}{c}\text { Nitrogen } \\
\text { management }\end{array}$} \\
\hline N1 & 3.10 & 3.31 & 3.20 & 14.44 & 14.74 & 14.59 & 21.97 & 22.09 & 22.03 \\
\hline N2 & 1.92 & 2.07 & 1.99 & 12.09 & 12.29 & 12.19 & 20.83 & 21.03 & 20.93 \\
\hline N3 & 2.89 & 3.07 & 2.98 & 15.65 & 15.51 & 15.58 & 22.17 & 22.33 & 22.25 \\
\hline N4 & 2.14 & 2.21 & 2.17 & 12.41 & 12.54 & 12.48 & 21.25 & 21.41 & 21.33 \\
\hline $\operatorname{SE}(d) \pm$ & 0.10 & 0.12 & 0.07 & 0.80 & 0.72 & 0.47 & 0.61 & 0.69 & 0.50 \\
\hline $\mathrm{CD}(\mathrm{p}=\mathbf{0 . 0 5})$ & 0.20 & 0.26 & 0.16 & 1.68 & 1.51 & 0.98 & NS & NS & NS \\
\hline \multicolumn{10}{|l|}{ Interaction } \\
\hline $\begin{array}{l}\text { SE }(d) \pm \text { for } \\
\text { NM on CE } \\
\text { methods }\end{array}$ & 0.17 & 0.21 & 0.13 & 1.38 & 1.24 & 0.81 & 1.06 & 1.20 & 0.86 \\
\hline $\begin{array}{l}\mathrm{CD}(\mathrm{p}=0.05) \\
\text { for NM on } \\
\text { CE methods }\end{array}$ & 0.35 & 0.45 & 0.27 & NS & NS & NS & NS & NS & NS \\
\hline $\begin{array}{l}\text { SE }(d) \pm \text { for } \\
\text { CE methods } \\
\text { on NM }\end{array}$ & 0.19 & 0.24 & 0.16 & 1.40 & 1.31 & 0.91 & 1.21 & 1.25 & 1.03 \\
\hline $\begin{array}{l}\mathrm{CD}(\mathrm{p}=0.05) \\
\text { for } \mathrm{CE} \\
\text { methods on } \\
\text { NM }\end{array}$ & 0.46 & 0.56 & 0.40 & NS & NS & NS & NS & NS & NS \\
\hline
\end{tabular}


Table.4 Effect of crop establishment methods and nitrogen management on leaf area index at 30, 60 and 90 DAT

\begin{tabular}{|c|c|c|c|c|c|c|c|c|c|}
\hline \multirow[t]{2}{*}{ Treatment } & \multicolumn{3}{|c|}{30 DAT } & \multicolumn{3}{|c|}{ 60 DAT } & \multicolumn{3}{|c|}{90 DAT } \\
\hline & 2016 & 2017 & Pooled & 2016 & 2017 & Pooled & 2016 & 2017 & Pooled \\
\hline \multicolumn{10}{|l|}{$\begin{array}{c}\text { Crop } \\
\text { establishment }\end{array}$} \\
\hline C1 & 0.83 & 0.86 & 0.85 & 3.08 & 3.60 & 3.34 & 4.75 & 5.11 & 4.93 \\
\hline $\mathrm{C} 2$ & 0.89 & 0.92 & 0.90 & 3.59 & 3.86 & 3.72 & 5.10 & 5.29 & 5.19 \\
\hline C3 & 0.94 & 1.02 & 0.98 & 4.36 & 4.59 & 4.48 & 6.55 & 6.64 & 6.60 \\
\hline $\operatorname{SE}(d) \pm$ & 0.07 & 0.05 & 0.05 & 0.24 & 0.33 & 0.15 & 0.40 & 0.30 & 0.23 \\
\hline $\mathrm{CD}(\mathrm{p}=0.05)$ & NS & 0.13 & NS & 0.66 & NS & 0.43 & 1.12 & 0.84 & 0.65 \\
\hline \multicolumn{10}{|l|}{$\begin{array}{c}\text { Nitrogen } \\
\text { management }\end{array}$} \\
\hline N1 & 1.08 & 1.10 & 1.09 & 3.60 & 4.07 & 3.83 & 5.53 & 5.76 & 5.65 \\
\hline N2 & 0.73 & 0.77 & 0.75 & 3.37 & 3.56 & 3.46 & 4.94 & 5.06 & 5.00 \\
\hline N3 & 0.90 & 0.97 & 0.93 & 4.23 & 4.50 & 4.37 & 6.09 & 6.50 & 6.30 \\
\hline N4 & 0.84 & 0.89 & 0.87 & 3.51 & 3.92 & 3.72 & 5.30 & 5.40 & 5.35 \\
\hline $\operatorname{SE}(d) \pm$ & 0.07 & 0.04 & 0.04 & 0.17 & 0.23 & 0.13 & 0.32 & 0.21 & 0.23 \\
\hline $\mathrm{CD}(\mathrm{p}=\mathbf{0 . 0 5})$ & 0.14 & 0.08 & 0.09 & 0.36 & 0.47 & 0.27 & 0.67 & 0.45 & 0.48 \\
\hline \multicolumn{10}{|l|}{ Interaction } \\
\hline $\begin{array}{l}\text { SE }(d) \pm \text { for } \\
\text { NM on CE } \\
\text { methods }\end{array}$ & 0.12 & 0.06 & 0.07 & 0.30 & 0.39 & 0.23 & 0.56 & 0.37 & 0.39 \\
\hline $\begin{array}{l}\mathrm{CD}(\mathrm{p}=0.05) \\
\text { for NM on } \\
\text { CE methods }\end{array}$ & NS & NS & NS & NS & NS & NS & NS & NS & NS \\
\hline $\begin{array}{l}\text { SE }(d) \pm \text { for } \\
\text { CE methods } \\
\text { on NM }\end{array}$ & 0.12 & 0.07 & 0.08 & 0.33 & 0.44 & 0.24 & 0.60 & 0.41 & 0.40 \\
\hline $\begin{array}{c}\mathrm{CD}(\mathrm{p}=0.05) \\
\text { for } \mathrm{CE} \\
\text { methods on } \\
\mathrm{NM}\end{array}$ & NS & NS & NS & NS & NS & NS & NS & NS & NS \\
\hline
\end{tabular}


Table.5 Effect of crop establishment methods and nitrogen management on effective tiller hill ${ }^{-1}$, panicle length $(\mathrm{cm})$ and test weight $(\mathrm{g})$

\begin{tabular}{|c|c|c|c|c|c|c|c|c|c|}
\hline \multirow[t]{2}{*}{ Treatment } & \multicolumn{3}{|c|}{ Effective tiller } & \multicolumn{3}{|c|}{ Panicle length } & \multicolumn{3}{|c|}{ Test weight } \\
\hline & 2016 & 2017 & Pooled & 2016 & 2017 & Pooled & 2016 & 2017 & Pooled \\
\hline \multicolumn{10}{|l|}{$\begin{array}{c}\text { Crop } \\
\text { establishment }\end{array}$} \\
\hline C1 & 22.13 & 23.00 & 22.56 & 22.97 & 23.18 & 23.08 & 30.12 & 30.29 & 30.20 \\
\hline $\mathrm{C} 2$ & 20.06 & 20.67 & 20.36 & 22.13 & 22.34 & 22.23 & 29.98 & 30.12 & 30.05 \\
\hline $\mathrm{C3}$ & 10.05 & 11.80 & 11.47 & 20.61 & 20.87 & 20.74 & 29.68 & 28.46 & 29.07 \\
\hline $\operatorname{SE}(d) \pm$ & 0.77 & 1.08 & 0.95 & 1.71 & 1.41 & 0.81 & 1.72 & 1.58 & 0.96 \\
\hline $\mathrm{CD}(\mathrm{p}=0.05)$ & 2.15 & 2.99 & 2.64 & NS & NS & NS & NS & NS & NS \\
\hline \multicolumn{10}{|l|}{$\begin{array}{c}\text { Nitrogen } \\
\text { management }\end{array}$} \\
\hline N1 & 17.96 & 19.61 & 18.95 & 22.97 & 23.02 & 22.99 & 29.97 & 29.74 & 29.86 \\
\hline N2 & 15.13 & 15.70 & 15.64 & 19.27 & 19.51 & 19.39 & 29.71 & 29.26 & 29.48 \\
\hline N3 & 19.53 & 20.74 & 20.31 & 23.13 & 23.37 & 23.25 & 30.15 & 29.92 & 30.04 \\
\hline N4 & 17.02 & 17.90 & 17.63 & 22.25 & 22.62 & 22.43 & 29.88 & 29.57 & 29.72 \\
\hline $\mathrm{SE}(\mathrm{d}) \pm$ & 0.62 & 0.55 & 0.48 & 1.07 & 1.22 & 0.68 & 1.25 & 0.86 & 0.93 \\
\hline $\mathrm{CD}(\mathrm{p}=0.05)$ & 1.30 & 1.15 & 1.01 & 2.25 & 2.56 & 1.42 & NS & NS & NS \\
\hline \multicolumn{10}{|l|}{ Interaction } \\
\hline $\begin{array}{l}\text { SE }(d) \pm \text { for } \\
\text { NM on CE } \\
\text { methods }\end{array}$ & 1.07 & 0.95 & 0.83 & 1.85 & 2.11 & 1.17 & 2.16 & 1.49 & 1.60 \\
\hline $\begin{array}{l}\mathrm{CD}(\mathrm{p}=0.05) \\
\text { for NM on } \\
\text { CE methods }\end{array}$ & NS & NS & NS & NS & NS & NS & NS & NS & NS \\
\hline $\begin{array}{l}\mathrm{SE}(\mathrm{d}) \pm \mathrm{CE} \\
\text { methods on } \\
\text { NM }\end{array}$ & 1.14 & 1.24 & 1.09 & 2.18 & 2.20 & 1.23 & 2.39 & 1.88 & 1.62 \\
\hline $\begin{array}{c}\mathrm{CD}(\mathrm{p}=0.05) \\
\text { for } \mathrm{CE} \\
\text { methods on } \\
\mathrm{NM}\end{array}$ & NS & NS & NS & NS & NS & NS & NS & NS & NS \\
\hline
\end{tabular}


Table.6 Effect of crop establishment methods and nitrogen management on grain $\left(\mathrm{t} \mathrm{ha}^{-1}\right)$ and straw $\left(\mathrm{t} \mathrm{ha}^{-1}\right)$ yield of rice

\begin{tabular}{|c|c|c|c|c|c|c|}
\hline \multirow[t]{2}{*}{ Treatment } & \multicolumn{3}{|c|}{ Straw yield } & \multicolumn{3}{|c|}{ Grain yield } \\
\hline & 2016 & 2017 & Pooled & 2016 & 2017 & Pooled \\
\hline \multicolumn{7}{|l|}{ Crop establishment } \\
\hline C1 & 6.18 & 6.29 & 6.23 & 4.67 & 4.80 & 4.73 \\
\hline C2 & 6.43 & 6.52 & 6.48 & 4.91 & 5.02 & 4.97 \\
\hline C3 & 5.56 & 5.62 & 5.59 & 3.51 & 3.61 & 3.56 \\
\hline $\mathrm{SE}(\mathrm{d}) \pm$ & 0.22 & 0.21 & 0.20 & 0.25 & 0.25 & 0.20 \\
\hline $\mathrm{CD}(\mathrm{p}=0.05)$ & 0.61 & 0.59 & 0.56 & 0.69 & 0.69 & 0.56 \\
\hline \multicolumn{7}{|l|}{$\begin{array}{c}\text { Nitrogen } \\
\text { management }\end{array}$} \\
\hline N1 & 6.27 & 6.31 & 6.29 & 4.43 & 4.52 & 4.47 \\
\hline N2 & 5.73 & 5.79 & 5.76 & 3.93 & 4.01 & 3.97 \\
\hline N3 & 6.38 & 6.55 & 6.46 & 5.03 & 5.23 & 5.13 \\
\hline N4 & 5.85 & 5.92 & 5.89 & 4.07 & 4.15 & 4.11 \\
\hline $\mathrm{SE}(\mathrm{d}) \pm$ & 0.21 & 0.19 & 0.14 & 0.17 & 0.16 & 0.14 \\
\hline $\mathrm{CD}(\mathrm{p}=0.05)$ & 0.45 & 0.39 & 0.28 & 0.36 & 0.34 & 0.30 \\
\hline \multicolumn{7}{|l|}{ Interaction } \\
\hline $\begin{array}{l}\text { SE }(d) \pm \text { for NM on } \\
\text { CE methods }\end{array}$ & 0.37 & 0.32 & 0.23 & 0.30 & 0.28 & 0.25 \\
\hline $\begin{array}{l}\mathrm{CD}(\mathrm{p}=0.05) \text { for } \mathrm{NM} \\
\text { on } \mathrm{CE} \text { methods }\end{array}$ & NS & NS & NS & NS & NS & NS \\
\hline $\begin{array}{l}\text { SE(d) } \pm \text { CE methods } \\
\text { on NM }\end{array}$ & 0.37 & 0.33 & 0.27 & 0.34 & 0.32 & 0.28 \\
\hline $\begin{array}{l}\mathrm{CD}(\mathrm{p}=0.05) \text { for } \mathrm{CE} \\
\text { methods on } \mathrm{NM}\end{array}$ & NS & NS & NS & NS & NS & NS \\
\hline
\end{tabular}

Nitrogen management also influence significantly on effective tiller hill $^{-1}$. Treatment N3-75\% RDN through urea $+25 \%$ RDN through FYM produces (20.31) significantly superior over N1-100\% RDN through Urea (18.95), N4-50\% RDN through Urea $+50 \% \mathrm{~N}$ through FYM (17.63) and N2$100 \% \mathrm{~N}$ through FYM (15.64). While panicle length and test weight found to be nonsignificant due to crop establishment methods. However, there was significance difference on panicle length due to nitrogen management. The results were in accordance with the finding of Sengar et al., (2000).
Effect of crop establishment method and nitrogen management on grain and straw yield

Yield is the final product of growth in vegetative phase and yield attribute like effective tiller, panicle length, fill grain and test weight. From the pooled data of grain yield ICM (4.97 $\mathrm{t} \mathrm{ha}^{-1}$ ) produces the highest grain yield which was at par with SRI (4.73 t $\left.\mathrm{ha}^{-1}\right)$ but significantly superior over conventional method $\left(3.56 \mathrm{t} \mathrm{ha}^{-1}\right)$. ICM was $4.82 \%$ and $28.32 \%$ higher over SRI and conventional method in grain yield production (Table 6). The reason for producing more 
grain yield in ICM might be due to production of more effective tiller meter ${ }^{-2}$ with more panicle length and number of grain similar finding was recorded from Latif et al., (2005), Thakurm et al., (2009) and Avasthe et al., (2012). Conventional method with closer spacing produces more tiller meter ${ }^{-2}$ due to higher plant population but thinner tiller, less panicle length and number of grain panicle ${ }^{-1}$.

The highest straw yield was also obtain from ICM which was at par with SRI but significantly higher over ICM which might be due to more number of tiller in ICM with more plant height.

Nitrogen management also has significant difference on grain yield and straw yield. Plot with treatment $\mathrm{N} 3-75 \%$ RDN through urea + $25 \%$ RDN through FYM (Table 6) produce highest grain and straw yield. There was a difference of $12.86 \%$ in grain yield from N3$75 \%$ RDN through urea $+25 \%$ RDN through FYM over $\mathrm{N} 1-100 \%$ RDN through Urea, $19.88 \%$ and $22.61 \%$ more grain yield over N4-50\% RDN through Urea $+50 \% \mathrm{~N}$ through FYM and N2-100 RDN through FYM.

This might be due to favorable soil condition and synchronized release of nutrient from the source which gives more dry matter accumulation, effective tiller, panicle length and grain panicle ${ }^{-1}$. Similar finding was also observed from Reddy et al., (2004).

\section{Acknowledgement}

The author is grateful to the authorities of College of Agriculture, Central Agricultural University, Manipur for providing field and support for making the Ph.D. research successful.

\section{References}

Archana Rajput, Sujit Singh Rajput and Girish Jha. 2017. Physiological Parameters
Leaf Area Index, Crop Growth Rate, Relative Growth Rate and Net Assimilation Rate of Different Varieties of Rice Grown Under Different Planting Geometries and Depths in SRI. Int. J. Pure App. Biosci. 5(1): 362-367.

Wahlang, B., Anup, D., Layek, J., Munda, G.C., Ramkrushna, G.I. and Panwar, A.S. 2015. Effect of establishment methods and nutrient management on physiological attributes and water-use efficiency of rice (Oryza sativa L.) in a sub-tropical climate. Indian J. Agron. 60(4): 534-540

Buresh R.J. and De Datta S.K. 1991. Nitrogen dynamics and management of ricelegume cropping system. Adv. Agron. 45: $1-59$

Fageria, N.K. and Baligar, V.C. 2005. Enhancing nitrogen use efficiency in crop plants. Adv. Agron. 88: 97-185.

Gill, M. S. and Meelu, O.P. 1982. Studies on the substitution of inorganic fertilizers with organic manures and their effect on the soil fertility in rice-wheat rotation. Fertilizer Research. 3: 30314.

Economic survey of Manipur, 2016-17: Directorate of economics and statistics, Government of Manipur.

Gomez, K.A. and Gomez, A.A. 1984. Statistical Procedure for Agricultural Research 2nd Edition, John Wiley and sons incorporation, New York. ISBN: 0-471-87931-2.

Islam, M., Nath, L.K., Patel, D.P., Das, A., Munda, G.C., Samajdar, T. and Ngachan, S.V. 2013. Productivity and socio-economic impact of system of rice intensification and integrated crop management over conventional methods of rice establishment in eastern Himalayas, India, Paddy Water Environment DOI 10.1007/s10333.

Latif, M.A., Islam, M.R., Ali, M.Y. and 
Saleque, M.A. 2005. Validation of the system of rice intensification (SRI) in Bangladesh. Field Crops Research. 93: 281-92.

Munda, G.C., Das, A. and Patel, D.P. 2007. Performance of lowland rice (Oryza sativa L.) as influenced by standestablishment methods and nutrientmanagement practices at mid-altitude of Meghalaya. (In:) Second National Symposium on SRI in India: Progress and Prospects - Papers and Extended Summaries, 3-5 October 2007, Agartala.

Prasad, R., Prasad., L.C. and Agarwal, R.K. 2010. Genetic diversity of Indian germplasm of Aromatic rice. Oryza. 46: 197-201.

Avasthe, R.K., Verma, S., Ashok Kumar and Rahman, H. 2012. Performance of rice (Oryza sativa L.) varieties at different spacing under system of rice intensification (SRI) in mid hill acid soils of Sikkim Himalayas. Indian J. of Agron. 57(1): 32-37.

Rajnesh Tomar, NB Singh, Vipul Singh and Devesh Kumar, 2018. Effect of planting methods and integrated nutrient management on growth parameters, yield and economics of rice. Journal of Pharmacognosy and Phytochemistry. 7(2): 520-527.

Reddy, M.M., Reddy, M.D., Reddy, B.B., 2004. Effect of N2 management through organic and inorganic sources on yield of rice. J. Research Angrau. 31(3):7-12.

Roy, D.K. and Mishra, S.S., 1999. Effect of weed management in direct-seeded, upland rice (Oryza sativa L.) at varying nitrogen levels. Indian $J$. Agron. 44: 105-108.

Sengar, S.S., Wade, L.J., Baghel, S.S. and Singh, R.K. 2000. Effect of Nutrient management on Rice in Rain-fed lowland of south east M.P. Indian J. of Agron. 45(2):315-322.

Singh, N.T. 1984. Green manures as a source of nutrients and production. (in) organic matter and rice. International Research Institute, Los Banos, Phillippines, 217-226.

Subbiah, S.V., Ramamoorthy, K., Kumar, R.R.M. and Singh, S.P. 2001. Studies on yield maximization through balanced nutrient ratios in irrigated lowland rice. Rice communication newsletter. 46: 59-61.

Thakur, A.K., Chaudhari, S.K., Singh, R. and Ashwani Kumar. 2009. Performance of rice varieties at different spacing grown by the system of rice intensification in eastern India. Indian J. of Agric. Sci. 79(6): 443-47.

Watson, D.J. 1952. The physiological basis of varieties in yield. Advances of Agron. 4: 101-145.

Yoshida, S. 1981. Fundamentals of Rice Crop Sci. International Rice Research Institute, Los Banos, Philippines. 269.

\section{How to cite this article:}

Khwairakpam Lenin Singh, Edwin Luikham, K. Nandini Devi and Priyanka Irungbam. 2019. Effect of Crop Establishment Methods and Nitrogen Management on Growth, Yield Attribute and Yield of Rice (Oryza sativa L.) under Lowland Condition of Manipur Valley. Int.J.Curr.Microbiol.App.Sci. 8(11): 47-58. doi: https://doi.org/10.20546/ijcmas.2019.811.006 